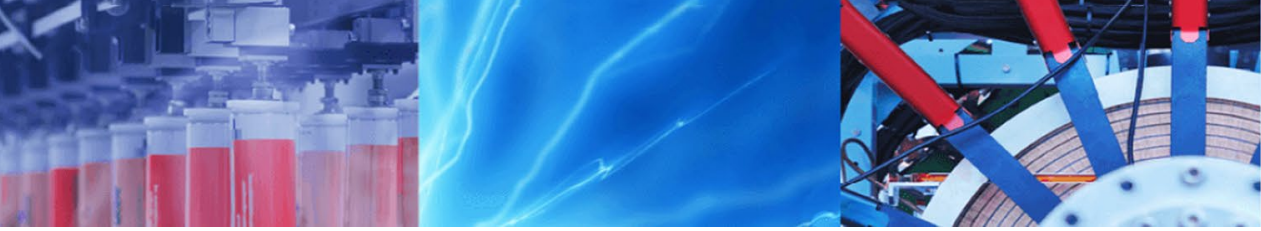

Research Article

\title{
Impact of catchment classification on streamflow regionalization in ungauged catchments
}

\author{
Janaki Ballav Swain ${ }^{1} \cdot$ Kanhu Charan Patra ${ }^{2}$
}

(c) Springer Nature Switzerland AG 2019

\begin{abstract}
Hydrological parameter transfer between dissimilar catchments is bound to be associated with errors. As a result of that, hydrological prediction at ungauged sites gets affected. If the catchments are similar to each other in some way, then it may reduce the error in prediction. The logic mentioned above is applied in the current study, where three regionalization approaches, i.e., Inverse Distance Weighted, Kriging and global mean based on spatial proximity between gauged and ungauged catchments, were applied on 32 catchments in India. Before application of regionalization techniques, 32 catchments were categorized into four homogeneous groups using the self-organizing map method. The improvement in streamflow regionalization was checked for both calibration (1995-2006) and validation (2007-2011) while moving from unclassified to classified catchments. Results suggest that prior classification of catchments into homogeneous groups helps in improving the regionalization output. Fifty per cent of the total catchments displayed 10\% improvement, while $30 \%$ of the catchments showed more than $10 \%$ improvement. The results imply that an appropriate combination of a hydrological model (Soil and Water Assessment Tool), regionalization technique and classification method will yield better results for ungauged catchments in streamflow prediction.
\end{abstract}

Keywords IDW · Kriging · Global mean ·SOM - Ungauged catchments

\section{Introduction}

Streamflow estimation in ungauged catchments always remains as one of the challenging tasks for hydrologists. The unavailability of long-term hydro-meteorological data is the primary cause of this. To make the matter worse, most of the river basins present across the globe are either partly gauged or entirely ungauged [1-3]. In some cases, hydrological parameter observation networks are continuously weakening [4]. Apart from that, due to less number of gauging stations for a large river basin, small watersheds are devoid of reckonable information [5]. Quantitative knowledge about the availability of water resources is very much important for many practical applications like flood estimation, watershed management operations, construction of hydraulic structures, etc. One way of streamflow estimation is to transfer the optimized hydrological model parameters from a gauged catchment to a nearby catchment that is ungauged. This process is called regionalization $[6,7]$.

In general, distributed physical models (MIKE-SHE and Mike 11 NAM), conceptual and semi-distributed models (HBV, IHACRES, SWAT) and data-driven models like Artificial Neural Network (ANN) are being used to simulate streamflow in both gauged and ungauged catchments [8]. In the case of ungauged catchments, it is not possible to calibrate a hydrological model due to the unavailability of long-term streamflow measurements. So regionalization is considered as a demanding job [1, 8-11]. In addition to this, most of the regionalization studies are region specific. The reason for that may be due to the effect of regional climate, human intervention and scale issues related to

$\triangle$ Janaki Ballav Swain, jnkballav.2009@gmail.com; Kanhu Charan Patra, kcpatra@nitrkl.ac.in | ${ }^{1}$ School of Civil Engineering, Lovely Professional University, Phagwara, Punjab 144411, India. ${ }^{2}$ Department of Civil Engineering, NIT Rourkela, Rourkela 769008, India.

SN Applied Sciences (2019) 1:456 | https://doi.org/10.1007/s42452-019-0476-6

Received: 3 February 2019 / Accepted: 9 April 2019 / Published online: 15 April 2019 
catchments. Hence, no universal regionalization method is present at the moment [9]. According to Razavi and Coulibaly [8], regionalization techniques can be grouped into two categories: hydrological model dependent and hydrological model independent. He et al. [12] apprised about the first category techniques, while Razavi and Coulibaly [8] reviewed extensively about continuous streamflow regionalization approaches covering both the categories.

Talking about hydrological model-dependent regionalization techniques, regression, spatial proximity, physical similarity are some of the most widely used methods to regionalize streamflow in ungauged catchments across the world $[2,9,11,13-23]$. The literature mentioned above is a few out of a huge pool of the literature about hydrological model-dependent regionalization. On the contrary, hydrological model-independent regionalization techniques do not have a rich history in case of ungauged catchment analysis. Use of Flow Duration Curve [24-27], General Regression Neural Network (GRNN) and CounterPropagation Network (CPN) with recurrent feedback loops [28], Artificial Neural Networks [29] are some of the examples of this category.

Beven [30] suggested that two catchments cannot be exactly similar to each other. In addition to this hypothesis, Ley et al. [31] stated that two nearby catchments exhibit contrasting behaviour. So extrapolation of streamflow estimates to dissimilar catchments is likely to be inaccurate irrespective of the regionalization techniques [6]. Classifying catchments to various homogeneous groups may be the primary step before application of regionalization techniques, which may improve the accuracy of the hydrological prediction in ungauged catchments [12]. Some popular techniques applied by previous researchers are cluster analysis, principal component analysis and multiple regression analysis to identify the homogeneous regions in ungauged catchment analysis [32-37].

As mentioned above, a lot of individual studies related to catchment classification or regionalization have been reported in the past. However, the effect of homogeneous regions on regionalization was demonstrated by a few researchers. Some of those studies are mentioned below. Application of classification techniques like Principal Component Analysis (PCA) and Canonical Correlation Analysis (CCA) before application of Self-Organizing Map (SOM) was demonstrated by Di Prinzio et al. [38]. Improved prediction results of streamflow indices such as mean annual run-off, mean annual flood and flood quantiles associated with given exceedance probabilities were obtained. Boscarello et al. [39] classified 46 ungauged catchments of Italy using SOM technique into three homogeneous groups before estimating Flow Duration Curve (FDC). Mean absolute percentage error reduced from 11 to $7 \%$ when regionalization technique was applied on classified catchments. The application of catchment classification methods; SOM, nonlinear PCA, compact nonlinear PCA before regionalization techniques; Inverse Distance Weighted (IDW), Multi-Layer Perceptron (MLP), CounterPropagation Neural Network (CPNN), and Support Vector Machine (SVM) improved the streamflow prediction results in ungauged catchments by more than $20 \%$ [40].

After the review of the available literature, it came to the fore that classifying catchments into homogeneous groups according to the similarity pattern have an impact on regionalization performance. Regional climate, catchment scale, human activities are some of the likely factors for which regionalization applications are case specific. However, an example of an organized application of catchment classification followed by regionalization in diverse climatic regions is very less documented. Hence, the present study is an attempt about the combination of catchment classification and regionalization approaches for streamflow prediction in ungauged catchments. SOM is used to classify the catchments into homogeneous groups, while spatial proximity (IDW, Kriging, global mean) is applied for streamflow regionalization. In a country like India where the issue of prediction in ungauged basins (PUB) is less addressed, the present study aims to analyse the potential improvement in streamflow regionalization results in pre-classified catchments over unclassified ones when applied in combination with a semi-distributed hydrological model SWAT (Soil and Water Assessment Tool).

\section{Methods}

\subsection{Study area and data}

The climatic conditions that prevail over India are extraordinary. Thirty-two catchments (Fig. 1) from the eastern and southern India spreading over nine river basins with minimum flow regulation were identified as the study area. The smallest basin encompasses $728-\mathrm{km}^{2}$ geographical area, while the largest one is $23,501 \mathrm{~km}^{2}$. A variation like geographical area can be seen in mean annual rainfall also in these basins with a minimum of $1000 \mathrm{~mm}$ to a maximum of $1400 \mathrm{~mm}$. (Source: India Meteorological Department). The key to rainfall in India is the southwest monsoon which lasts from July to October. Apart from that, southern India gets a substantial portion of their annual rainfall during October and November because of the northeast monsoon. The central and eastern parts of India experience the high temperature of around $44{ }^{\circ} \mathrm{C}$ during May and June. December and January are the coldest months with temperature as low as $5^{\circ} \mathrm{C}$. While in the southern part of India, summer is hot and humid with a high temperature 
Fig. 1 Thirty-two Indian catchments used in the study

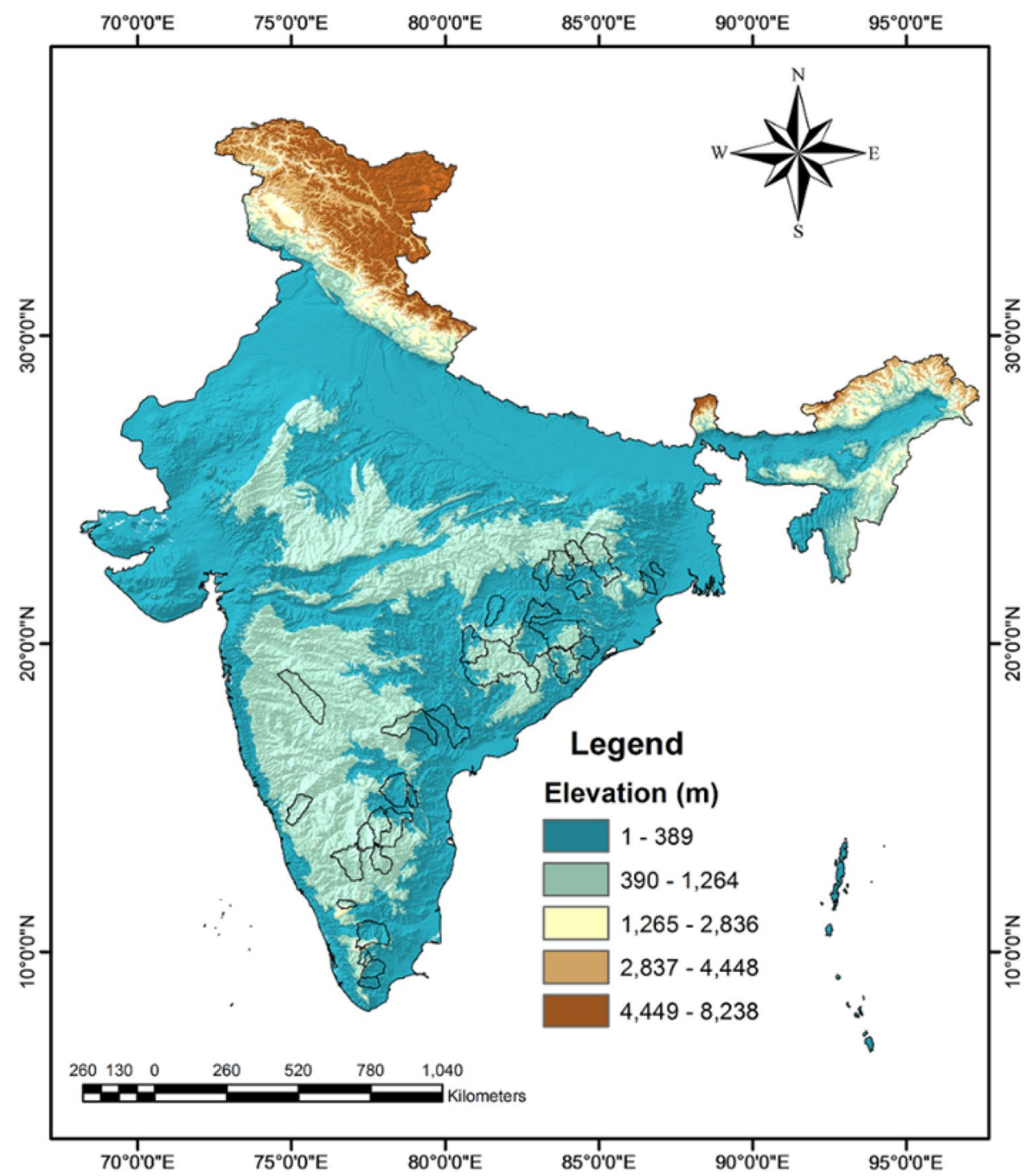

of $45^{\circ} \mathrm{C}$, winter is pleasing with a minimum temperature of $15^{\circ} \mathrm{C}$. Topography of the catchments in these regions accommodates a large variation.

Daily rainfall data of the study area were collected from the India Meteorological Department (IMD) for the period of the year 1990 to 2011. Similarly, daily streamflow measurement records were collected for the same period from India-WRIS database (http://www.india-wris.nrsc.gov.in/ wris.html). The land use database is collected from Bhuvan (http://bhuvan.nrsc.gov.in/), and soil data are collected from the Food and Agriculture Organization of United Nations (http://www.fao.org/soils-portal/).

\subsection{Catchment classification}

In the current study, regionalization techniques were applied to a single group of thirty-two catchments, followed by the unchanged course of events for several homogeneous groups consisting of the same 32 catchments. Homogeneity among groups was established based on eight catchment attributes (Table 1) and streamflow properties. Based on the recommendation of the literature reviewed, both linear and nonlinear classification

Table 1 Catchment attributes selected for classification

\begin{tabular}{ll}
\hline Catchment attribute & Unit \\
\hline Latitude & Degree \\
Longitude & Degree \\
Catchment area & Square kilometre \\
Mean slope & $\%$ \\
Mean elevation & $\mathrm{meter}$ \\
Drainage density & $\mathrm{km} / \mathrm{km}^{2}$ \\
Area covered with forest & $\%$ \\
Rapid drainage soil profile & $\%$ \\
\hline
\end{tabular}


techniques were tested to classify thirty-two catchments. Principal Component Analysis (PCA) along with K-means clustering was used as a linear technique, while SelfOrganizing Map (SOM) and Kernel PCA (KPCA) were the two nonlinear classification methods used to organize the catchments into uniform groups.

\subsubsection{Principal Component Analysis (PCA) and K-means clustering}

Being one of the simplest multivariable dimension reduction techniques that orthogonally converts the correlated variables into a smaller set of linearly uncorrelated variables (principal components), PCA was applied on catchment attributes and daily streamflow time series. This technique uses the eigenvector breakdown of the covariance matrix of the variables taken as input. The lesser number of principal components than the number of original variables makes the analysis easier. K-means clustering was used to separate the boundaries of the principal component scores [37]. K-means algorithm assigns an $\mathrm{N}$-dimensional population into $\mathrm{K}$ set of groups where every data point fits the cluster with the nearest mean. The Davies-Bouldin index (DBI) familiarized by Davies and Bouldin, [41] is a tool for evaluation of the clustering algorithm. This index is calculated based on inter- and intracluster distance between the centroids of the clusters. The lower index implies a compact and appropriate cluster.

$\mathrm{DBI}=\frac{1}{n} \sum_{i, j=1, i \neq j}^{n} \max \left(\frac{D_{i}+D_{j}}{\left|C_{i}-C_{j}\right|}\right)$

where $D_{i}, D_{j}$ are the average intracluster distances of all points to the centre of that cluster and $C_{i}-C_{j}$ is the intercluster distance between the centre of the two clusters. The number of groups or clusters was decided based on lowest Davies-Bouldin index (DBI) score [40].

\subsubsection{Self-Organizing Map (SOM)}

Kohonen $[42,43]$ introduced a neural network algorithm, i.e. SOM, an unsupervised learning method to analyse, cluster and model various types of large database [44, 45]. SOM technique groups the samples or patterns into predefined classes and arranges the classes into meaningful maps [45]. The output of the SOM method can be represented in the form of a discrete lattice of neurons. The ability of this technique is to represent its results in an uncomplicated way directly in terms of original variables which makes it one of the most popular techniques in this field. In addition to that, the technique deals with nonlinear variables. In the present study, eight catchment attributes were taken as input for the SOM approach.

\subsubsection{Kernel PCA}

KPCA is a nonlinear form of standard PCA. It is an extension of traditional PCA over a high-dimensional space using kernel function [46]. In case of dispersed uncorrelated variables in a two-dimensional space, PCA is unable to ease the dimensionality, because of scattering of data without following a straight line. In such cases, kernel PCA can find this nonlinear manifold and find out the linearity present in data. Both catchment attributes and daily streamflow time series were used for the application of KPCA, which has not been applied in the field of catchment classification as far as our knowledge is concerned.

Four streamflow signatures [run-off ratio, slope of flow duration curve, Base Flow Index (BFI) and streamflow elasticity] were estimated from streamflow, rainfall and temperature used as inputs for K-means clustering. This classification was considered as reference classification, and other classifications were compared with it. The streamflow signatures express the hydrological phenomena occurs within the catchment in terms of quality as well as quantity [37]. Homogeneity of a cluster was determined by discordancy measure, while the comparison between reference classification and rest of the techniques (PCA, SOM and KPCA) was quantified by similarity index (SI). The detailed description of the classification methods is presented in [47]. Figure 2 demonstrates the stepwise application of classification techniques in the current study.

Similarity Index $(\mathrm{SI})=\frac{1}{2}\left(\frac{1-|X \backslash Y|+|Y \backslash X|-|X \cap Y|}{|X|+|Y|}\right)$

where $|X|$ and $|Y|$ symbolize the cardinality of set $X$ and $Y$ correspondingly. $|X \backslash Y|$ is the cardinality of set difference of $X$ from $Y$, and for $|Y \backslash X|$ it is the contrary.

Set $X$ was considered clusters obtained from the reference classification technique, while the other classification techniques were represented by set $Y$.

\subsection{SWAT calibration and validation}

SWAT is a semi-distributed, continuous hydrological model which functions on a daily timescale to predict the impact of land management on water, sediment and water quality of large ungauged basins [48]. Weather, hydrology, erosion, plant growth, nutrients, pesticides, land management and stream routing are some of the key modules of SWAT [48]. This model divides the large watershed into many sub-watersheds, and it is further subdivided into a series of hydrological response units (HRUs), a unique 
Fig. 2 Flowchart representing the catchment classification scheme

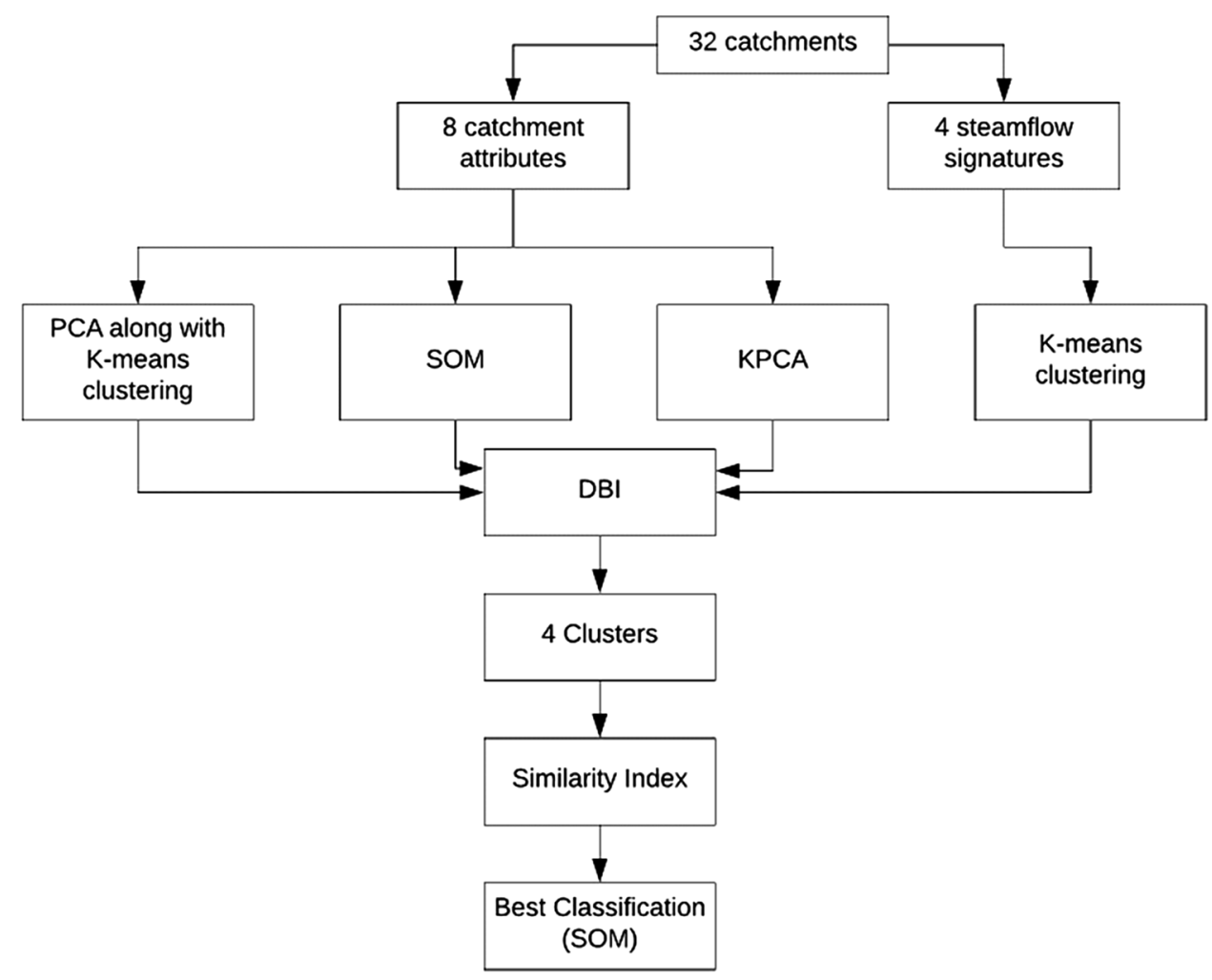

combination of land use, soil and slope. When parameters are simulated, it is first estimated for each HRU, and then, it is accumulated for the whole watershed as a weighted average [49].

SWAT model was calibrated against observed streamflow data. The total length of the time series data was separated into three phases: model warm up (1990-1994), calibration (1995-2006) and validation (2007-2011). SWATCUP was used to calibrate the model. The parameters used for calibration are presented in Table 2 with the physical significance of each parameter and range of parameters used. The optimized parameters were used to validate the model without further adjustment in the range of parameters.

Three model performance evaluation criteria were selected based on the recommendation of Moriasi et al. [50]. Those are Nash-Sutcliffe efficiency (NSE), RMSEobservations standard deviation ratio (RSR) and per cent bias (PBIAS).

Nash-Sutcliffe efficiency [51] is a measure of correlation, bias and variability [52], which is one of the widely used criteria for performance evaluation all over the world by researchers [23]. Usually, NSE varies between $-\infty$ and 1. A value of 1 points towards a perfect match between observed and simulated value. A value of NSE $\leq 0$ suggests that the model is no better than the observed mean value $[23,52]$. Per cent bias (PBIAS) was chosen because it measures the average tendency of the simulated data to be larger or smaller than their observed counterparts, and it detects poor model performances [52]. A positive value represents a bias towards underestimation, while a negative value suggests a model bias towards overestimation and zero represents the optimal value [53]. A value of $\pm 25 \%$ can be considered a satisfactory result in case of streamflow estimation [54]. RSR combines the benefits of error index statistics which includes a scaling or normalization factor $[23,50]$. RSR varies from zero to a large positive value. The optimal value ' $O$ ' represents null RMSE or residual variation, i.e. a perfect model simulation [50]. The mathematical expression of these indicators is as follows:

$\mathrm{NSE}=1-\left(\frac{\sum_{i=1}^{t}\left(\left(Q_{\mathrm{obs}}-Q_{\mathrm{sim}}\right)^{2}\right)}{\sum_{i=1}^{t}\left(\left(Q_{\mathrm{obs}}-\bar{Q}_{\mathrm{obs}}\right)^{2}\right)}\right)$

$\mathrm{RSR}=\frac{\mathrm{RMSE}}{\mathrm{STDEV}_{\mathrm{obs}}}=\frac{\sqrt{\sum_{i=1}^{t}\left(Q_{\mathrm{obs}}-Q_{\text {sim }}\right)^{2}}}{\sqrt{\sum_{i=1}^{t}\left(Q_{\mathrm{obs}}-\bar{Q}_{\mathrm{obs}}\right)}}$

PBIAS $=100 \times \frac{\sum_{i=1}^{t}\left(Q_{\mathrm{obs}}-Q_{\mathrm{sim}}\right)_{i}}{\sum_{i=1}^{t} Q_{\mathrm{obs}, i}}$ 
Table 2 SWAT parameters used in the study

\begin{tabular}{|c|c|c|c|c|}
\hline \multirow[t]{2}{*}{ Parameters } & \multirow[t]{2}{*}{ Description } & \multicolumn{2}{|c|}{$\begin{array}{l}\text { Range of param- } \\
\text { eters }\end{array}$} & \multirow[t]{2}{*}{$\begin{array}{l}\text { Fitted value } \\
\text { (average) }\end{array}$} \\
\hline & & Min & Max & \\
\hline${ }^{*} \mathrm{r} \_\mathrm{CN} 2$ & Initial SCS run-off curve number for moisture condition II & -0.2 & 0.2 & -0.033 \\
\hline${ }^{*} v_{\text {__GW_DELAY }}$ & Groundwater delay time (days) & 30 & 450 & 320.979 \\
\hline v_ALPHA_BF & Baseflow alpha factor (1/days) & 0 & 1 & 0.451 \\
\hline *a_GWQMN & $\begin{array}{l}\text { Threshold depth of water in the shallow aquifer required for return flow to occur } \\
\qquad\left(\mathrm{mm} \mathrm{H}_{2} \mathrm{O}\right)\end{array}$ & 0 & 25 & 12.178 \\
\hline V__GW_REVAP & Groundwater revap coefficient & 0 & 0.2 & 0.102 \\
\hline$r \_$REVAPMN & Threshold depth of water in the shallow aquifer for revap to occur $\left(\mathrm{mm} \mathrm{H}_{2} \mathrm{O}\right)$ & 0 & 10 & 4.267 \\
\hline r_SOL_AWC & Available water capacity of the first soil layer $\left(\mathrm{mm} \mathrm{H}_{2} \mathrm{O} / \mathrm{mm}\right.$ soil) & -0.2 & 0.4 & 0.142 \\
\hline $\mathrm{V} \_$ESCO & Soil evaporation compensation factor & 0.8 & 1 & 0.879 \\
\hline r__SOL_K & Saturated hydraulic conductivity $(\mathrm{mm} / \mathrm{hr})$ & -0.8 & 0.8 & 0.109 \\
\hline V_ALPHA_BNK & Baseflow alpha factor for bank storage (days) & 0 & 1 & 0.375 \\
\hline $\mathrm{v} \_\mathrm{CH} \_\mathrm{K} 2$ & Effective hydraulic conductivity in main channel alluvium $(\mathrm{mm} / \mathrm{hr})$ & 5 & 130 & 118.208 \\
\hline V_EPCO & Plant uptake compensation factor & -0.8 & 1 & 0.103 \\
\hline r_HRU_SLP & Average slope steepness (m/m) & 0 & 0.2 & 0.133 \\
\hline $\mathrm{v} \_$CH_N2 & Manning's $n$ value for the main channel & 0 & 0.3 & 0.195 \\
\hline r_OV_N & Manning's $n$ value for overland flow & -0.2 & 0 & -0.052 \\
\hline$r \_S L S U B B S N$ & Average slope length (m) & 0 & 0.2 & 0.188 \\
\hline r__SOL_BD & Moist bulk density $\left(\mathrm{Mg} / \mathrm{m}^{3}\right)$ & -0.5 & 0.6 & 0.147 \\
\hline V_SURLAG & Surface run-off lag coefficient & 1 & 10 & 5.430 \\
\hline
\end{tabular}

${ }^{*} v_{\text {_ }}$ means the existing parameter value which is to be replaced by a given value, ${ }^{*} a_{-}$stands for a given value which is added to the existing parameter value, ${ }^{*}{ }_{\text {r }}$ represents an existing parameter value which is multiplied by ( $1+$ the given value)

where $Q_{\text {obs }}$ and $Q_{\text {sim }}$ represent the observed and simulated streamflow, respectively, while $\bar{Q}_{\mathrm{obs}}$ is the mean of the observed streamflow and $t$ is the number of observation.

\subsection{Regionalization}

Transfer of optimized parameters from gauged catchments to ungauged catchments was carried out using the following regionalization techniques: Inverse Distance Weighted (IDW), Kriging and global mean. A detailed stepwise implementation of regionalization techniques is presented in Fig. 3.

\subsubsection{IDW}

IDW technique works with a known set of points spread around an unknown point, the value of that is estimated using a weighted average of the values of known points. In case of catchment studies, it is based on the inverse spatial distance of the centroid of the catchment [55]. For estimation of model parameters in ungauged catchments, all the 32 catchments were treated as ungauged, one by one [23].

\subsubsection{Global mean}

In the case of global mean method, the model parameter values of the ungauged catchment are estimated using arithmetic mean of the optimized parameters obtained from gauged catchments.

\subsubsection{Kriging}

Kriging is an advanced and more sophisticated geostatistical technique than IDW used to interpolate values from sample data onto a grid of points for contouring [56]. The weights in the Kriging are calculated from variograms that measure the degree of correlation among samples based on distance and direction between them. Out of the many Kriging methods, ordinary Kriging method was used for interpolation with a nugget of $10 \%$ of the observed variance, a sill equal to variance. One of the reasons for selecting Kriging was the promising results obtained by previous researchers by applying it on a large number of basins $[11,16,17,57]$. Furthermore, this method does not require additional parameter calibration. 
Fig. 3 Flowchart representing regionalization approach in classified as well as unclassified catchments

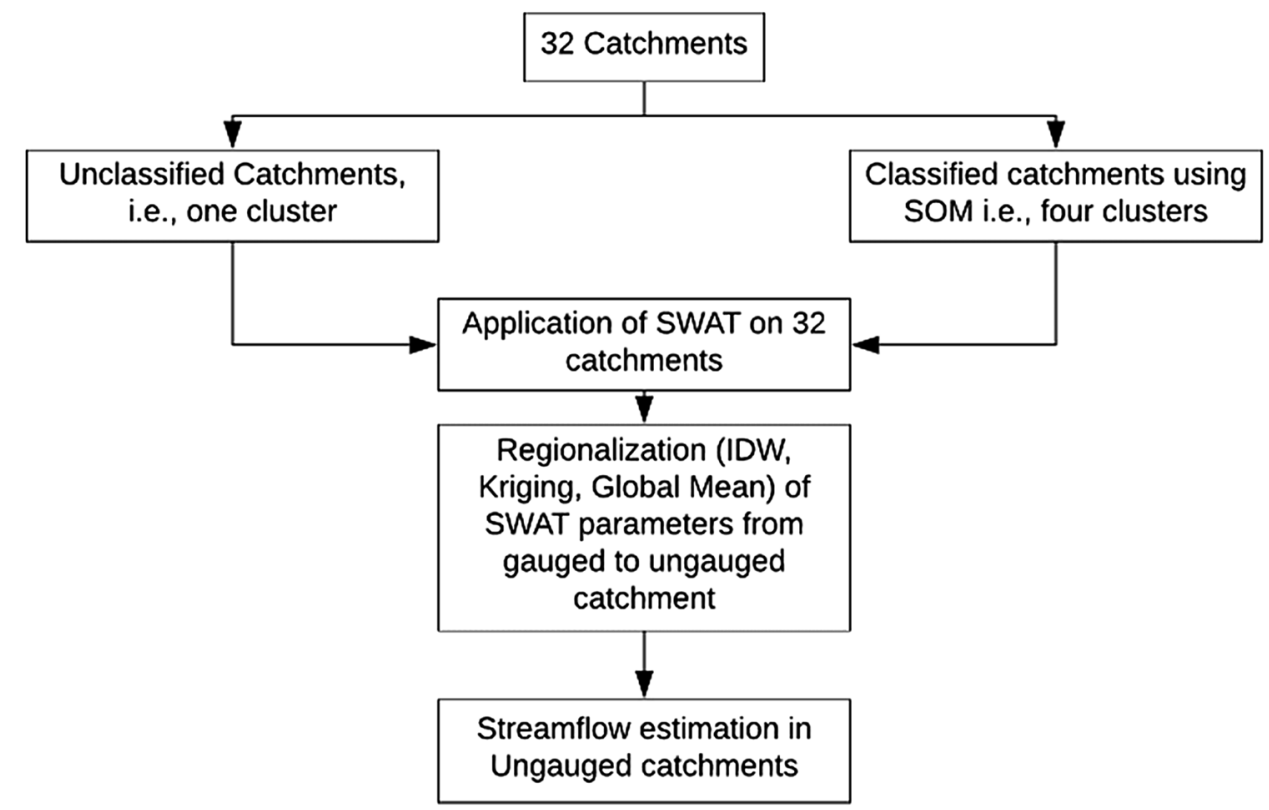

\section{Results}

PCA result suggests that the first four PCs hold more than $70 \%$ of variation that can be considered as an appropriate percentage of variance for dimension reduction. The application of K-means clustering along with DBI created four clusters. The same number of clusters was obtained from SOM and KPCA method. However, the similarity of catchments in terms of their distribution to different clusters in SOM was closely matched with that of the reference classification. Hence, SOM was further considered as the best classification technique. Figure 4 demonstrates the distribution of catchments into four clusters with the application of SOM.

The overall results obtained from the application of the semi-distributed SWAT model in 32 catchments can be categorized as 'good'. Coming to the results of the SWAT model calibration and validation, the median values of the three model performance indicators (NSE, RSR and PBIAS) are $0.70,0.25$ and $16.80 \%$ during calibration, and $0.63,0.26$ and $12.50 \%$ during validation period, respectively. Most of the NSE values are above 0.6 and above 0.5 during the calibration period and validation period, respectively, suggesting a satisfactory performance of the SWAT model for most of the catchments. The range of RSR values is found between 0.07 and 0.95 , and PBIAS is within the acceptable range. The results mentioned above suggest the SWAT model is capable enough to reproduce the seasonal variation in streamflow in the selected catchments.

The regionalization techniques were carried out using three spatial proximity approaches, i.e. IDW, Kriging and global mean, in combination with the SWAT model on both classified and unclassified catchments during calibration as well as validation periods. Based on the analysis and results obtained [47], the self-organizing map technique was selected for the classification of catchments into four suitable clusters.

IDW and Kriging produced competitive results for both unclassified and classified catchments, whereas global mean approach is least productive. Table 3 presents the minimum, median, mean and maximum values of NSE, RSR and PBIAS during calibration and validation periods for three regionalization techniques on both unclassified and classified catchments. It is evident from Table 3 that the results are improved when the regionalization techniques are applied on classified catchments to that of unclassified ones. In general, the minimum NSE values have shown improvement over unclassified catchments to classified ones, irrespective of the regionalization methods. There is a decrease in RSR values for each of the regionalization technique for classified catchments. Overall, PBIAS values have shown marginal improvement in case of classified catchments than unclassified ones. To quantify the improvement in results, the percentage of improvement was estimated. A positive value represents a better performance, while a negative value suggests the declining effect of catchment classification on streamflow regionalization.

Classifying the catchments into homogeneous clusters has a negative impact on a few $(8 \%)$ catchments. The classification scheme is based on similarity in catchment attributes. However, few catchments are grouped with those catchments which are similar in terms of attributes but located distantly from each other. This might have 
Fig. 4 Distribution of catchments into four clusters using SOM [47]

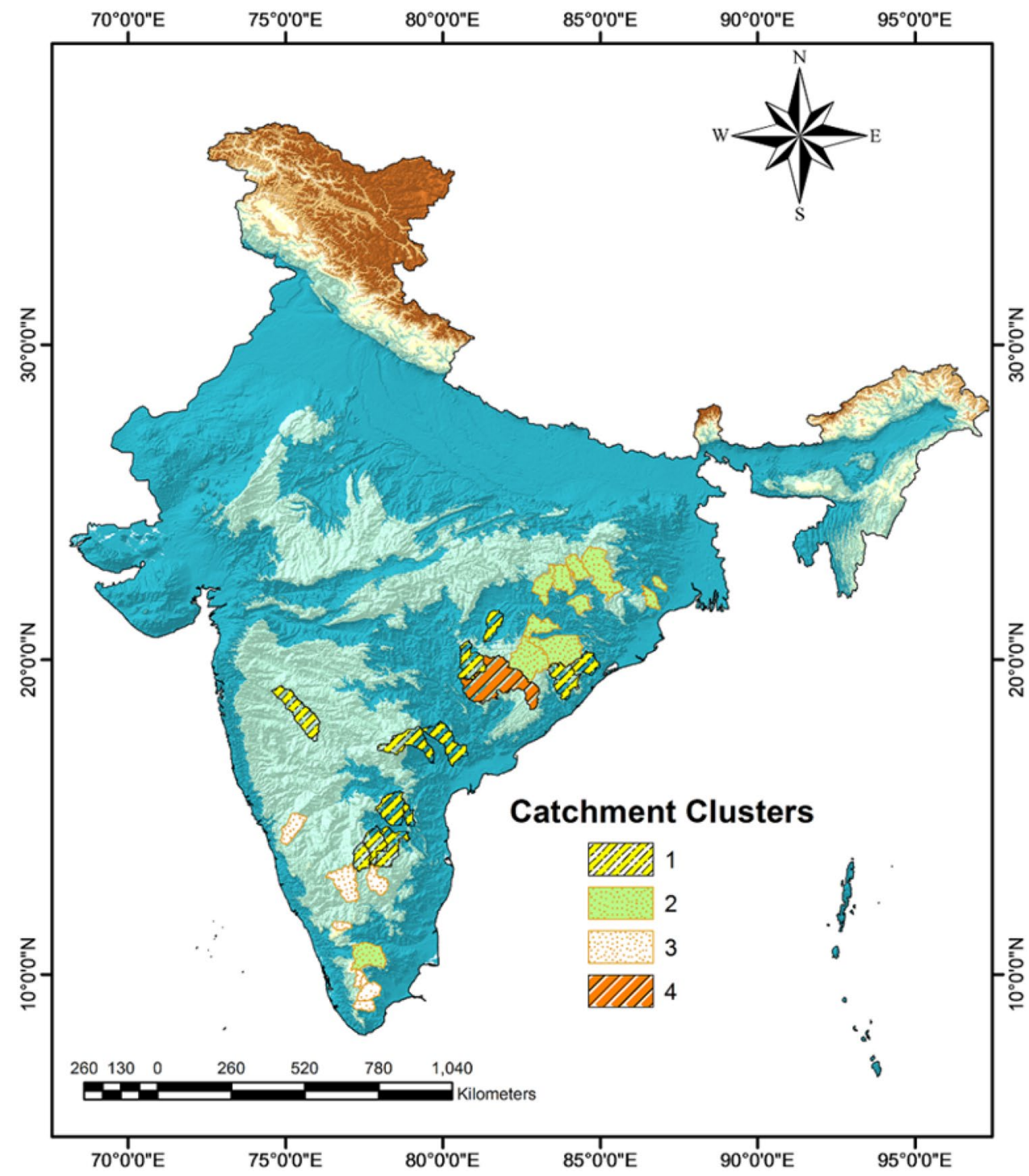

affected the regionalization performance, which is based on spatial distance. Half of the catchments (56\%) exhibit 0-10\% improvement, while $33 \%$ of catchments exhibit $10-20 \%$ improvement. Only $2 \%$ of the total catchments show improvement greater than $20 \%$. The impact of catchment classification on each catchment is presented in terms of panel maps (Figs. 5, 6 and 7).

\subsection{Discussion}

Regional climate, soil types and vegetation are a few elements which make the regionalization studies explicit [27]. Most of the selected SWAT parameters are linked to these factors. The identified model and objective of the study decide the appropriateness of the regionalization approach. A different model or change of SWAT parameters might have produced different results. A few more morphological parameters such as land use class and soil group may be added to the list of catchment attributes. The results of this study suggest that an appropriate combination of hydrological model, classification technique and regionalization method may yield good results. Though there is a negative impact of classification on regionalization results for few catchments, overall it improves the results. In the current study, the regionalization approaches are based on the spatial distance between gauged and ungauged catchments. For example, the regionalization model performance for two catchments located in the western part of the study area and relatively isolated from the group declined after classification. 


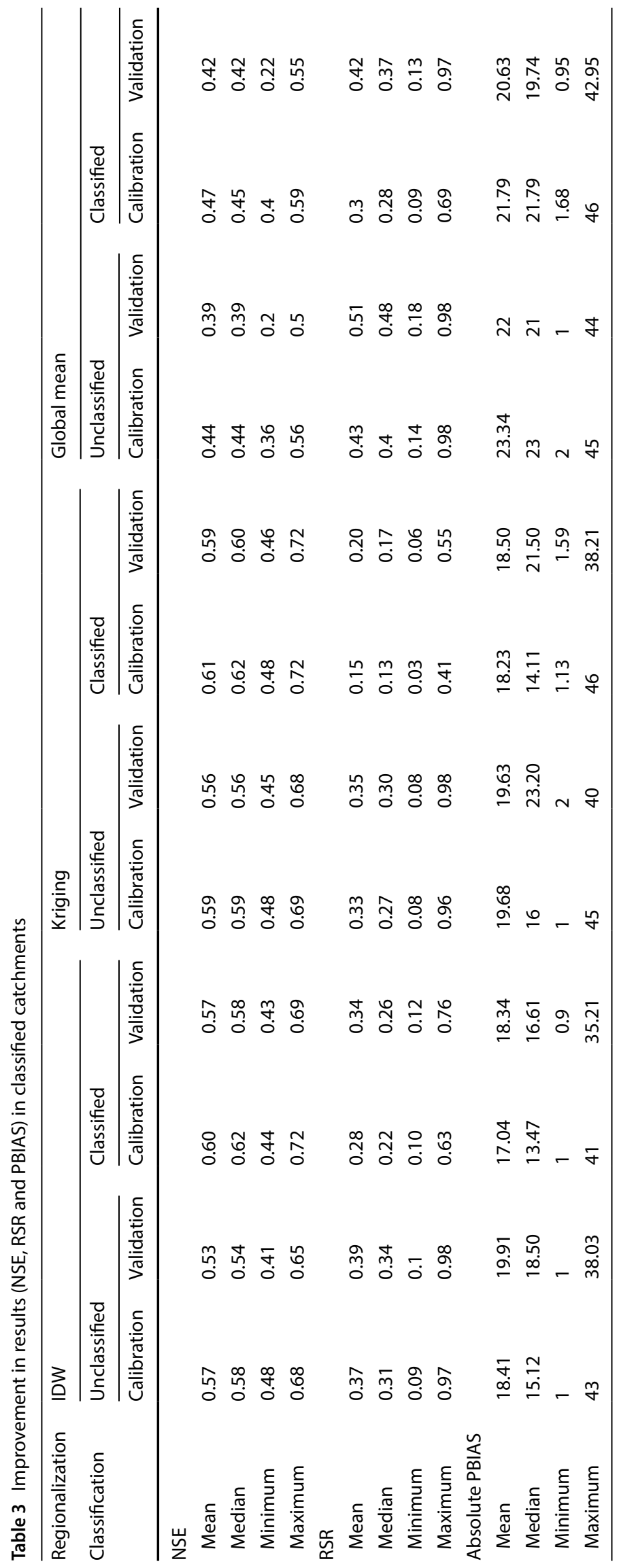


Similar results are obtained for a catchment placed centrally in the study area. These catchments are grouped with catchments which are similar to each other in terms of their attributes but located distant to each other. Though catchment classification improves the results of regionalization, still densely gauged catchment network is required for better performance of spatial proximity methods. The implemented classification techniques are self-sufficient and not dependent on either landscape or scale of the catchment. SOM being a nonlinear classification technique produced best results among all the classification techniques.

The number of catchments considered for this study is relatively less compared to the other studies $[9,11$, 17], but the geographical area of each catchment is bigger than most of the studies. The regionalization results suggest that catchments having smaller drainage area have shown greater improvement than the bigger ones. The reason behind this may be the selected catchment attributes which are capable enough to represent the hydrological processes occurring within a smaller drainage area rather than a bigger one. In addition to this those catchments where land cover is dominant by agricultural lands, improvement is higher after classification. One of the limitations in this study is that the above-mentioned methodologies are applied considering the peripheral environment as stationary. Application of all these techniques in the real non-stationary world may provide more genuine results.

\section{Conclusions}

Three spatial proximity regionalization techniques (IDW, Kriging and global mean) were applied on 32 unclassified and classified (SOM) catchments to check the effectiveness of homogeneous region on streamflow prediction. The process was carried out for calibration (1995-2006) and validation (2007-2011) period.

Overall results suggest an improvement when regionalization techniques were applied on classified catchments. IDW and Kriging produced competitive results and superior to results of global mean technique. Half of the catchments exhibit $10 \%$ of improvement in regionalization
Fig. 5 Effect of catchment classification on NSE of regionalization results during a calibration period and $\mathbf{b}$ validation period in terms of percentage increase/decrease
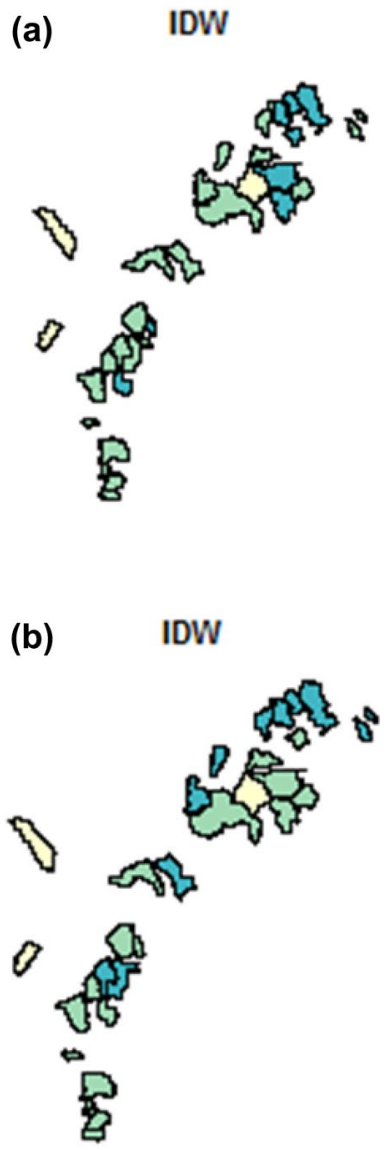
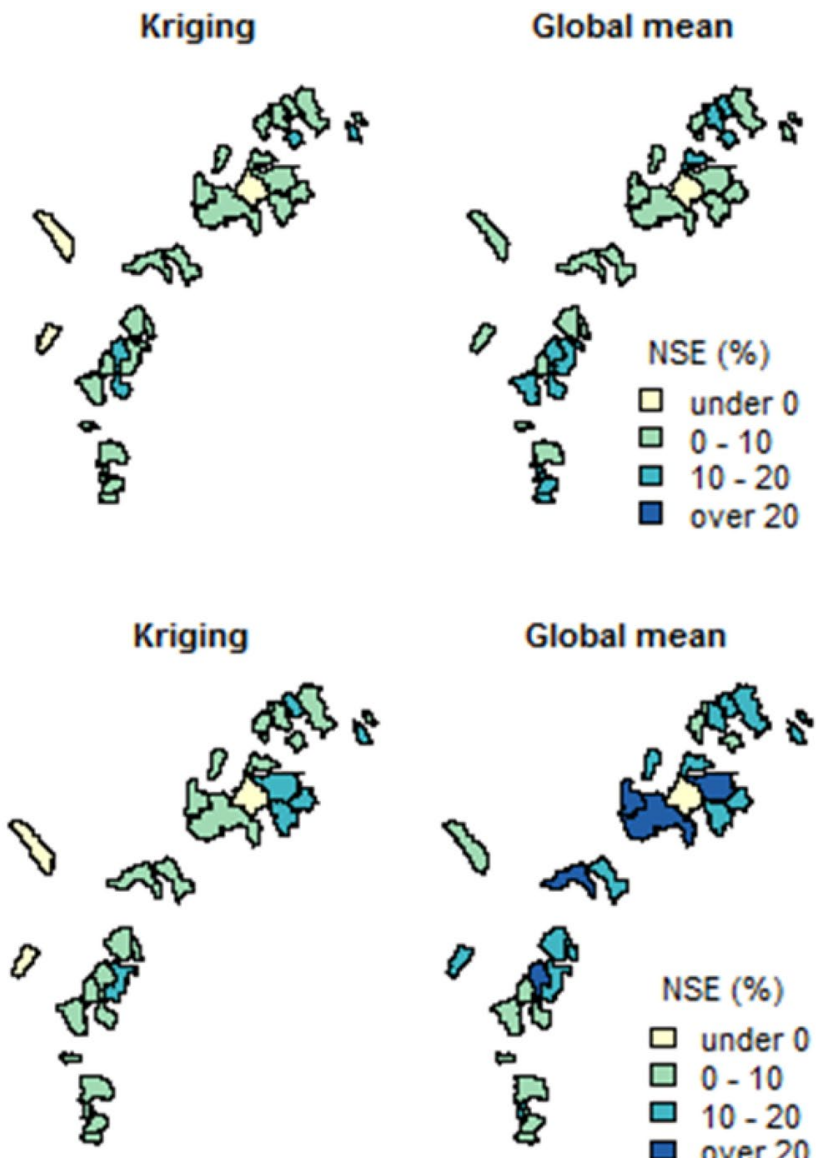

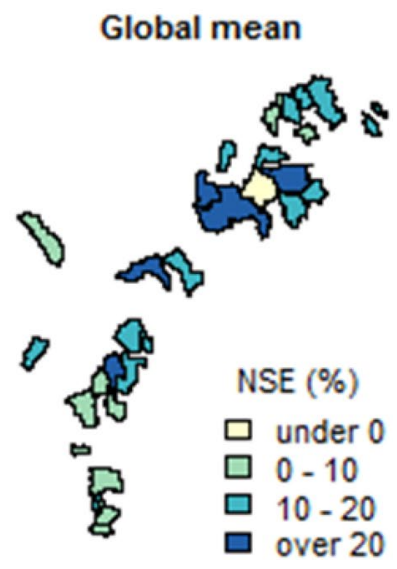


Fig. 6 Effect of catchment classification on RSR of regionalization results during a calibration period and $\mathbf{b}$ validation period in terms of percentage increase/decrease
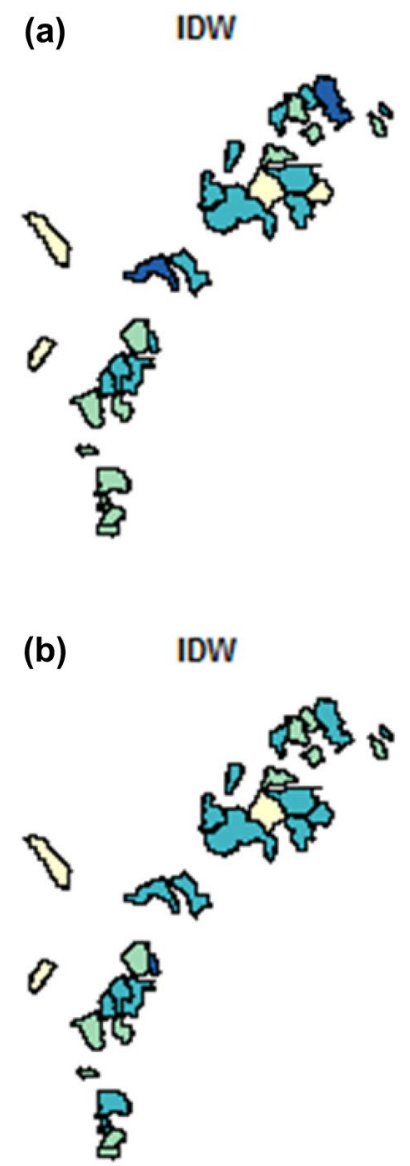

results when grouped along with similar catchments. The results suggest that the catchment classification method should be the primary step before application of regionalization technique in ungauged catchment analysis.
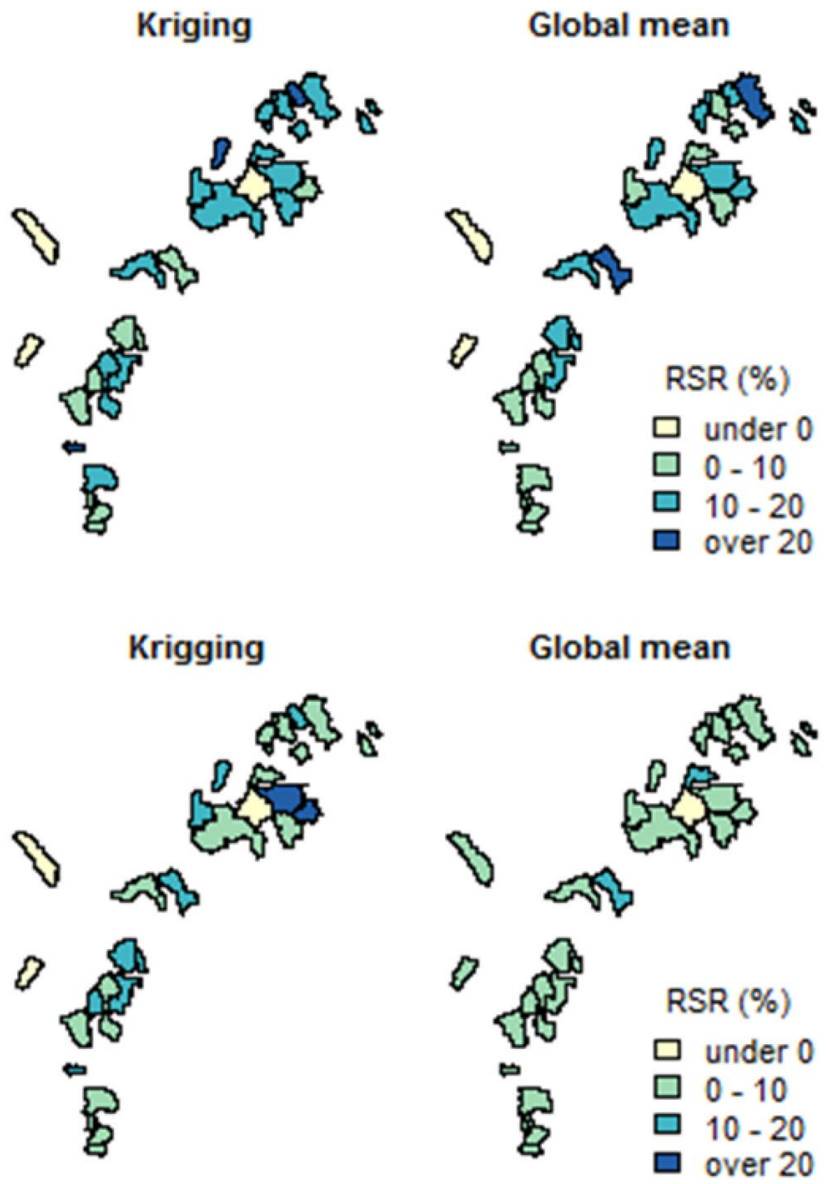

Catchment classification helps in getting closer predicted streamflow values to that of observed ones, which is necessary for the ungauged catchment. 
Fig. 7 Effect of catchment classification on PBIAS of regionalization results during a calibration period and $\mathbf{b}$ validation period in terms of percentage increase/decrease
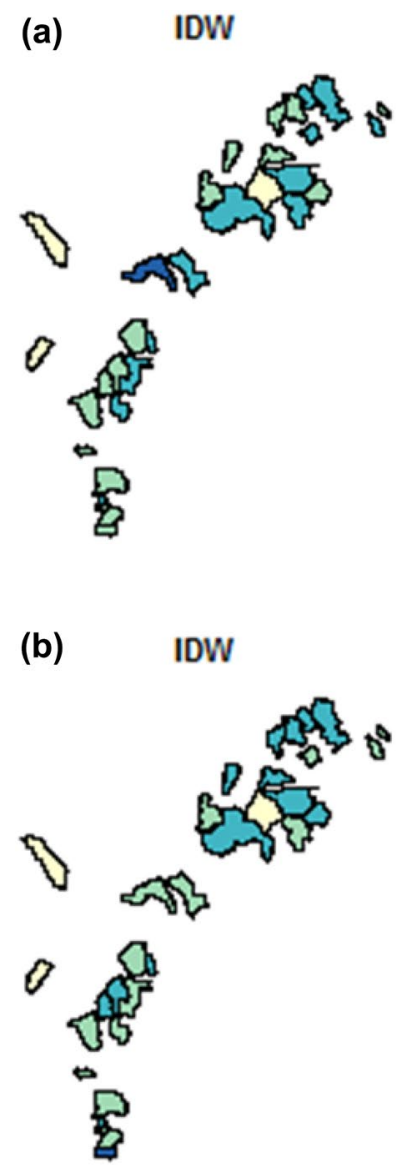

Acknowledgements The authors would like to acknowledge the IMD and CWC, India, for providing the hydrological data required for this study.

\section{Compliance with ethical standards}

Conflict of interest On behalf of all authors, the corresponding author states that there is no conflict of interest.

\section{References}

1. Sivapalan M, Takeuchi K, Franks SW, Gupta VK, Karambiri H, Lakshmi V, Liang X, McDonnell JJ, Mendiondo EM, O'connell PE, Oki $T$, Zehe $E$ (2003) IAHS decade on predictions in ungauged basins (PUB), 2003-2012: shaping an exciting future for the hydrological sciences. Hydrol Sci J 48(6):857-880. https://doi.org/10.1623/ hysj.48.6.857.51421

2. Young AR (2006) Stream flow simulation within UK ungauged catchments using a daily rainfall-runoff model. J Hydrol 320(12):155-172. https://doi.org/10.1016/j.jhydrol.2005.07.017

3. Blöschl G, Sivapalan M, Wagener T, Viglione A, Savenije H (2013) Runoff prediction in ungauged basins: synthesis across processes, places and scales. Eos Trans Am Geophys Union 95:22. https://doi.org/10.1017/CBO9781139235761
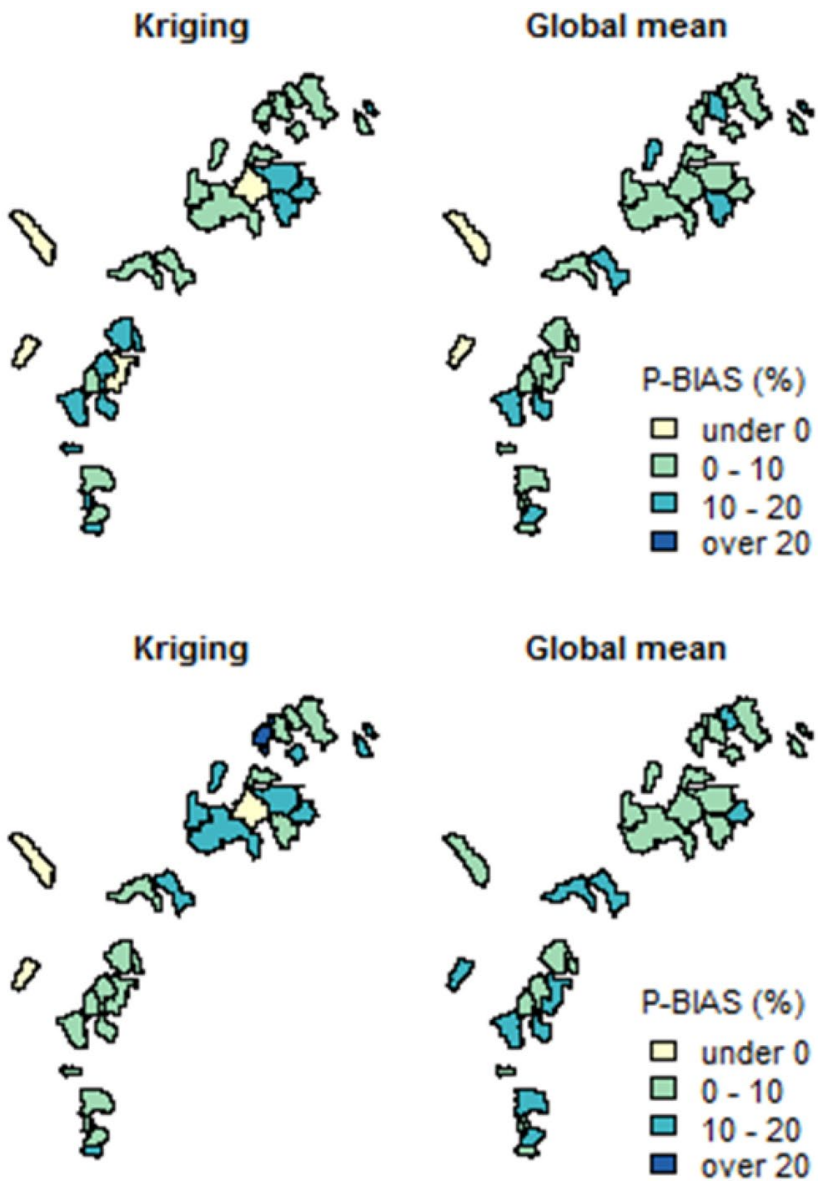

4. Mishra AK, Coulibaly P (2009) Developments in hydrometric network design: a review. Rev Geophys 47(2):1-24. https://doi. org/10.1029/2007RG000243

5. Ibrahim B, Wisser D, Barry B, Fowe T, Aduna A (2015) Hydrological predictions for small ungauged watersheds in the Sudanian zone of the Volta basin in West Africa. J Hydrol Reg Stud 4:386397. https://doi.org/10.1016/j.ejrh.2015.07.007

6. Blöschl G, Sivapalan M (1995) Scale issues in hydrological modelling: a review. Hydrol Process 9:251-290. https://doi. org/10.1002/hyp.3360090305

7. Oudin L, Kay A, Andréassian V, Perrin C (2010) Are seemingly physically similar catchments truly hydrologically similar? Water Resour Res 46(11):1-15

8. Razavi T, Coulibaly P (2012) Streamflow prediction in ungauged basins: review of regionalization methods. J Hydrol Eng. https:// doi.org/10.1061/(ASCE)HE.1943-5584.0000690

9. Oudin L, Andréassian V, Perrin C, Michel C, Le Moine N (2008) Spatial proximity, physical similarity, regression and ungaged catchments: a comparison of regionalization approaches based on 913 French catchments. Water Resour Res 44(3):1-15. https ://doi.org/10.1029/2007WR006240

10. Stoll S, Weiler M (2010) Explicit simulations of stream networks to guide hydrological modelling in ungauged basins. Hydrol Earth Syst Sci 14(8):1435-1448. https://doi.org/10.5194/ hess-14-1435-2010

11. Samuel J, Coulibaly P, Metcalfe RA (2011) Estimation of continuous streamflow in Ontario ungauged basins: comparison of regionalization methods. J Hydrol Eng 16(5):447-459. https ://doi.org/10.1061/(ASCE)HE.1943-5584.0000338 
12. He Y, Bárdossy A, Zehe E (2011) A review of regionalisation for continuous streamflow simulation. Hydrol Earth Syst Sci 15(11):3539-3553. https://doi.org/10.5194/hess-15-3539-2011

13. Sefton CEM, Howarth SM (1998) Relationships between dynamic response characteristics and physical descriptors of catchments in England and Wales. J Hydrol 211(1-4):1-16. https://doi. org/10.1016/S0022-1694(98)00163-2

14. Post DA, Jakeman AJ (1999) Predicting the daily streamflow of ungauged catchments in S.E. Australia by regionalising the parameters of a lumped conceptual rainfall-runoff model. Ecol Model 123(2-3):91-104. https://doi.org/10.1016/S0304 -3800(99)00125-8

15. Kokkonen TS, Jakeman AJ, Young PC, Koivusalo HJ (2003) Predicting daily flows in ungauged catchments: model regionalization from catchment descriptors at the Coweeta Hydrologic Laboratory, North Carolina. Hydrol Process 17(11):2219-2238. https://doi.org/10.1002/hyp.1329

16. Merz R, Blöschl G (2004) Regionalisation of catchment model parameters. J Hydrol 287(1-4):95-123. https://doi.org/10.1016/j. jhydrol.2003.09.028

17. Parajka J, Merz R, Blöschl G (2005) A comparison of regionalisation methods for catchment model parameters. Hydrol Earth Syst Sci Dis 9:157-171. https://doi.org/10.5194/hessd $-2-509-2005$

18. Heuvelmans G, Muys B, Feyen J (2006) Regionalisation of the parameters of a hydrological model: comparison of linear regression models with artificial neural nets. J Hydrol 319(14):245-265. https://doi.org/10.1016/j.jhydrol.2005.07.030

19. Kay AL, Jones DA, Crooks SM, Kjeldsen TR, Fung CF (2007) An investigation of site-similarity approaches to generalisation of a rainfall-runoff model. Hydrol Earth Syst Sci Dis 11(1):500-515. https://doi.org/10.5194/hess-11-500-2007

20. Masih I, Uhlenbrook S, Maskey S, Ahmad MD (2010) Regionalization of a conceptual rainfall-runoff model based on similarity of the flow duration curve: a case study from the semi-arid Karkheh basin, Iran. J Hydrol 391(1-2):188-201. https://doi. org/10.1016/j.jhydrol.2010.07.018

21. Sellami H, La Jeunesse I, Benabdallah S, Baghdadi N, Vanclooster M (2014) Uncertainty analysis in model parameters regionalization: a case study involving the SWAT model in Mediterranean catchments (Southern France). Hydrol Earth Syst Sci 18(6):23932413. https://doi.org/10.5194/hess-18-2393-2014

22. Razavi T, Coulibaly P (2016) An evaluation of regionalization and watershed classification schemes for continuous daily streamflow prediction in ungauged watersheds. Can Water Resour J [Revue Canadienne Des Ressources Hydriques] 1784(June):119. https://doi.org/10.1080/07011784.2016.1184590

23. Swain JB, Patra KC (2017) Streamflow estimation in ungauged catchments using regionalization techniques. J Hydrol 554:420433. https://doi.org/10.1016/j.jhydrol.2017.08.054

24. Isik S, Singh VP (2008) Hydrologic regionalization of watersheds in Turkey. J Hydrol Eng 13(9):824-834. https://doi.org/10.1061/ (ASCE) 1084-0699(2008)13:9(824)

25. Mohamoud YM (2008) Prediction of daily flow duration curves and streamflow for ungauged catchments using regional flow duration curves. Hydrol Sci J 53(4):706-724. https://doi. org/10.1623/hysj.53.4.706

26. Müller MF, Thompson SE (2016) Comparing statistical and process-based flow duration curve models in ungauged basins and changing rain regimes. Hydrol Earth Syst Sci 20(2):669-683. https://doi.org/10.5194/hess-20-669-2016

27. Swain JB, Patra KC (2017) Streamflow estimation in ungauged catchments using regional flow duration curve: comparative study. J Hydrol Eng 22(7):4017010. https://doi.org/10.1061/ (ASCE)HE.1943-5584.0001509
28. Besaw LE, Rizzo DM, Bierman PR, Hackett WR (2010) Advances in ungauged streamflow prediction using artificial neural networks. J Hydrol 386(1-4):27-37. https://doi.org/10.1016/j.jhydr ol.2010.02.037

29. Lima CHR, Lall U (2010) Spatial scaling in a changing climate: a hierarchical Bayesian model for non-stationary multi-site annual maximum and monthly streamflow. J Hydrol 383(3-4):307-318. https://doi.org/10.1016/j.jhydrol.2009.12.045

30. Beven JK (2000) Uniqueness of place and process representations in hydrological modelling. Hydrol Earth Syst Sci 4(2):203213. https://doi.org/10.5194/hess-4-203-2000

31. Ley R, Casper MC, Hellebrand H, Merz R (2011) Catchment classification by runoff behaviour with self-organizing maps (SOM). Hydrol Earth Syst Sci 15(9):2947-2962. https://doi.org/10.5194/ hess-15-2947-2011

32. Nathan RJ, McMahon TA (1990) Identification of homogeneous regions for the purposes of regionalisation. J Hydrol 121(14):217-238. https://doi.org/10.1016/0022-1694(90)90233-N

33. Burn DH, Boorman DB (1992) Catchment classification applied to the estimation of hydrological parameters at ungauged catchments, vol 143. Institute of Hydrology, Wallingford, pp 429-454. https://doi.org/10.1016/0022-1694(93)90203-L

34. Chiang S-M, Tsay T-K, Nix SJ (2002) Hydrologic regionalization of watersheds. I: methodology development. J Water Resour Plan Manag 128(1):3-11

35. Rao AR, Srinivas VV (2006) Regionalization of watersheds by fuzzy cluster analysis. J Hydrol 318(1-4):57-79. https://doi. org/10.1016/j.jhydrol.2005.06.004

36. Sawicz K, Wagener T, Sivapalan M, Troch PA, Carrillo G (2011) Catchment classification: empirical analysis of hydrologic similarity based on catchment function in the eastern USA. Hydrol Earth Syst Sci 15(9):2895-2911. https://doi.org/10.5194/ hess-15-2895-2011

37. Razavi T, Coulibaly P (2013) Classification of Ontario watersheds based on physical attributes and streamflow series. J Hydrol 493:81-94. https://doi.org/10.1016/j.jhydrol.2013.04.013

38. Di Prinzio M, Castellarin A, Toth E (2011) Data-driven catchment classification: application to the pub problem. Hydrol Earth Syst Sci 15(6):1921-1935. https://doi.org/10.5194/ hess-15-1921-2011

39. Boscarello L, Ravazzani G, Cislaghi A, Mancini M (2015) Regionalization of flow-duration curves through catchment classification with streamflow signatures and physiographic-climate indices. J Hydrol Eng ASCE 21(3):5015027

40. Razavi T, Coulibaly $P$ (2016) Improving streamflow estimation in ungauged basins using multi-modelling approach. Hydrol Sci J 61(15):2668-2679. https://doi.org/10.1080/02626 667.2016.1154558

41. Davies DL, Bouldin DW (1979) A cluster separation measure. IEEE Trans Pattern Anal Mach Intell 1(2):224-227. https://doi. org/10.1109/TPAMI.1979.4766909

42. Kohonen $T$ (1982) Analysis of a simple self-organizing process. Biol Cybern 44(2):135-140. https://doi.org/10.1007/BF00317973

43. Kohonen $T$ (1982) Self-organized formation of topologically correct feature maps. Biol Cybern 43(1):59-69. https://doi. org/10.1007/BF00337288

44. Huang D, Yi Z, Pu X (2008) A new local PCA-SOM algorithm. Neurocomputing 71(16-18):3544-3552. https://doi.org/10.1016/j. neucom.2007.10.004

45. Kalteh AM, Hjorth P, Berndtsson R (2008) Review of the selforganizing map (SOM) approach in water resources: analysis, modelling and application. Environ Model Softw 23(7):835-845. https://doi.org/10.1016/j.envsoft.2007.10.001

46. Shawe-Taylor J, Cristianini N (2004) Kernel methods for pattern analysis. Elements, vol 47. Cambridge University Press, Cambridge. https://doi.org/10.1017/CBO9780511809682 
47. Swain JB, Sahoo MM, Patra KC (2016) Homogeneous region determination using linear and nonlinear techniques. Phys Geogr 37(5):361-384. https://doi.org/10.1080/02723 646.2016 .1211460

48. Arnold JG, Srinivasan R, Muttiah RS, Williams JR (1998) Large area hydrologic modeling and assessment part I: model development. J Am Water Resour Assoc. https://doi. org/10.1111/j.1752-1688.1998.tb05961.x

49. Abbaspour KC, Yang J, Maximov I, Siber R, Bogner K, Mieleitner J, Zobrist J, Srinivasan R (2007) Modelling hydrology and water quality in the pre-alpine/alpine Thur watershed using SWAT. J Hydrol 333(2-4):413-430. https://doi.org/10.1016/j.jhydr ol.2006.09.014

50. Moriasi DN, Arnold JG, Van Liew MW, Binger RL, Harmel RD, Veith TL (2007) Model evaluation guidelines for systematic quantification of accuracy in watershed simulations. Trans ASABE 50(3):885-900. https://doi.org/10.13031/2013.23153

51. Nash JE, Sutcliffe JV (1970) River flow forecasting through conceptual models part I-a discussion of principles. J Hydrol 10(3):282-290. https://doi.org/10.1016/0022-1694(70)90255-6

52. Gupta HV, Kling H, Yilmaz KK, Martinez GF (2009) Decomposition of the mean squared error and NSE performance criteria: implications for improving hydrological modelling. J Hydrol 377(1-2):80-91. https://doi.org/10.1016/j.jhydrol.2009.08.003
53. Gupta HV, Sorooshian S, Yapo PO (1999) Status of automatic calibration for hydrologic models: comparison with multilevel expert calibration. J Hydrol Eng 4(2):135-143

54. Van Liew MW, Veith TL, Bosch DD, Arnold JG (2007) Suitability of SWAT for the conservation effects assessment project: comparison on USDA agricultural research service watersheds. J Hydrol Eng 12(2):173-189. https://doi.org/10.1061/ (ASCE) 1084-0699(2007)12:2(173)

55. Shepard D (1968) A two-dimensional interpolation function for irregularly-spaced data. In: 23rd ACM National Conference, pp 517-524. https://doi.org/10.1145/800186.810616

56. Vandewiele GL, Elias A (1995) Monthly water balance of ungauged catchments obtained by geographical regionalization. J Hydrol 170(1-4):277-291. https://doi.org/10.1016/00221694(95)02681-E

57. Parajka J, Blöschl G, Merz R (2007) Regional calibration of catchment models: potential for ungauged catchments. Water Resour Res 43(6):1-16. https://doi.org/10.1029/2006WR005271

Publisher's Note Springer Nature remains neutral with regard to jurisdictional claims in published maps and institutional affiliations. 